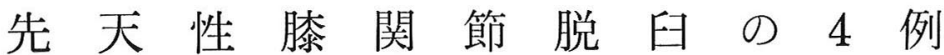 \\ 鳥取大学医学部附属病院整形外科

$\begin{array}{llll}\text { 折 } & \text { 隆・山上剛 } \\ \text { 河 野 龍之助 }\end{array}$

\section{Congenital Dislocation of the Knee-4 Cases}

by

\author{
T. Orito, T. Yamagami and R. Kono \\ Department of Orthopedic Surgery, Tottori \\ University School of Medicine
}

\begin{abstract}
Congenital dislocation of the knee is rare.
We had 4 cases for 10 years from 1969 to 1979,3 cases were female, one male.

The affected knee was hyperextended with a prominent protuberance in the popliteal space and a crease over the anterior aspect of the joint.

The loss of flexion was obvious.

Of these, 2 cases had pes valgus, one had congenital dislocation of the hip, and one had a deformity of the toe. In all cases, the satisfactory result was given with the early conservative treatment.
\end{abstract}

先天性膝関節脱臼は比較的まれな疾患で 1810 年 代 に Malacarne, Chausier, Chatalaine などが初め て記載した. 1936 年三木の 12 例を最初として諸家の 追加報告を散見する．最近われわれは自動屈曲不能で あり，膝窝部に大腿骨顆部を触知しうる本疾患 4 症例 4 関節を経験したので若干の文献的考察を加えて報告 する.

\section{症例 1 生後 2 日の女坚}

既往歴 正常頭位分婏にて出生した

現病歴 出生直後に産科医より左滕関節の過伸展を 指摘され翌日当科に紹介された。

現症 左膝関節は約 50 度の過伸展を呈し，左膝窩 部には大腿骨顆部を触知し，自動屈曲不能であった。 左股関節脱臼を合併していた。

治療 左溙関節脱臼に対しては, 衰引整復後, 軽度 屈曲位にて 4 週間のギプスシーネ固定し軽快した，左 股関節脱臼に対しては, 生後 3 ケ月より $\mathrm{R}-\mathrm{B}$ 装着 し軽快した.

症例 2 生後 2 日の男児

既往歷 正常頭位分娩にて出生した

現病歴 出生直後に産科医により左膝関節過伸展を
指摘され翌日当科㳊介された。

現症 左膝関節は約 70 度の過伸展を呈し，自動届 曲不能であった．左膝関節前部には数条のひだをみ， 膝蓋骨を触知した．膝窝部には大腿骨顆部を触知し た.エックス線像では舞脱囦を呈している（図 1).

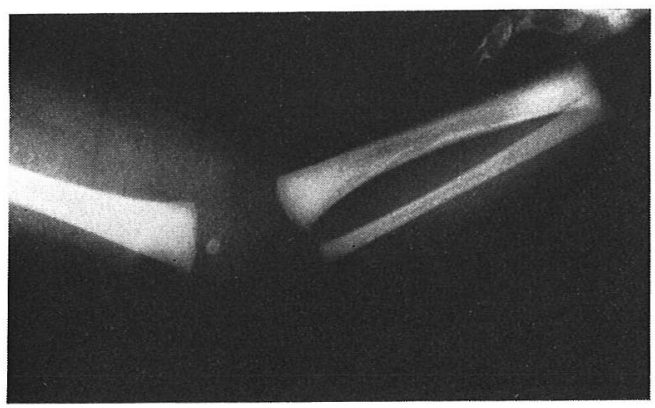

図 1

治療 徒手整復後メタルシーネ固定し，安定したた め18日後に除去した.

症例 3 生後 2 日の女児

既往歷 早期破水，頭位分婏にて出生した.

現病歴 出生直後に左膝関節の過伸展と右鉤足を指 


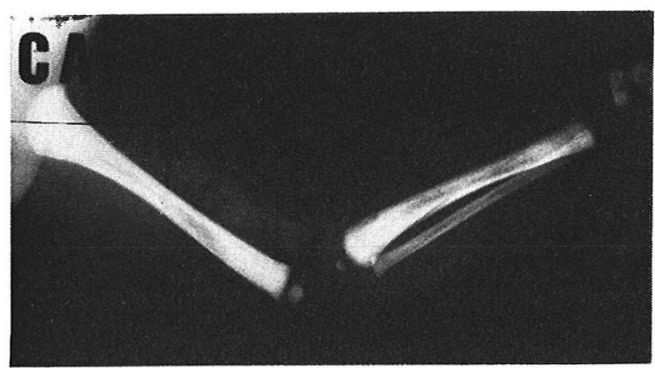

図 2

摘されて翌日当科汇紹介された。

現症 左膝関節は約 60 度の過伸展を呈し，関節 前 部にひだを認め，膝窩部には大腿骨顆部を触知した。 自動屈曲不能であり，他動的に屈曲するとクリックを 呈し整復された、また右鉤足を合併していた、エック ス線像では亜脱臼を呈する（図2）。

治療 徒手整復後メタルシーネ固定を 4 週間し他動 的にあ脱臼がみられなくなったため除去した．右銁足 に対しては, メタルシーネ固定をしたまま 33 日後大 阪医科大学を紹介した.

症例 4 生後 1 日の女览

既往歷 妊娠中毒症の他異常なく頭位分娩にて出生 した.

現病歴 出生直後に右滕関節の過伸展を指摘され同 日当科を紹介された。

現症 右膝関節は約 40 度の過伸展を呈し，関節 前 部にひだを認め，膝简部には大腿骨顆部を触知し自動 屈曲は不能であった．右鉤足を合併していた．整復 4 日後のエックス線像では脱臼位を呈していない（図 3 ).

以上をまとめると表 1 の如くである.

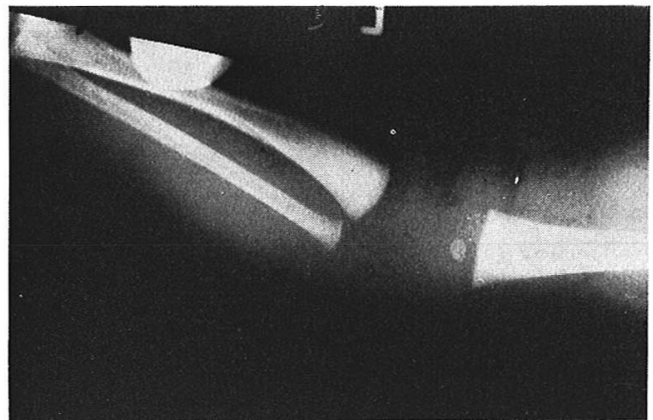

図 3

考

察

先天性膝関節脱曰日 Kopits によると先天性 奇形 の $0.43 \%$ \%ある. 性差は女児に多いといわれるが， わ机机の症例屯女児 3 例, 男児 1 例と女児に多加。 た. Drehmann によると 1) 前方脱臼 2) 後方脱臼 3 ）外側脱臼 4) 前後方脱臼 5 ) 任意脱臼之分類して いるが，ほとんどが前方脱臼である．前方脱臼をさら 飞第 1 度反張膝, 第 2 度亜脱臼, 第 3 度完全脱臼之分 類している. われわれの症例は, 症例 1 , 症例 2 , 症 例 3 は第 2 度, 症例 4 は第 3 度であった（表 1 ）。 ま た本疾患は他に奇形を合併するととが多い，最も多い 奇形は先天性股関節脱其といわれている，文献にみら れる奇形は松森によると表 2 のでとくである．われわ れの症例では, 症例 1 亿先天性股関節脱臼を, 症例 2 には足趾の变形，症例 3 , 症例 4 には鈎足を合併して いた．本疾患の原因としては，Middleton の大腿四 頭筋拘縮, Drehmann, Mayer の子宮内での異常肢 位, Hussein, Kopits の中胚葉性の欠損などいろい ろいわれている. 1947 年 Provenzano は内因性（子

表 $\quad 1$

\begin{tabular}{|c|c|c|c|c|c|c|c|c|}
\hline 症例 & 性 & $\begin{array}{l}\text { 発見侍 } \\
\text { 年 令 }\end{array}$ & 左右 & $\begin{array}{l}\text { Drehmann } \\
\text { 分 類 }\end{array}$ & 弤娠及び分婏歴 & 療 & 予後 & 合 併 症 \\
\hline 1 & 女 & 出生侍 & 左 & 度 & $\begin{array}{l}\text { 第 } 2 \text { 子頭位分晚 } \\
\text { 出生時体重2740 g }\end{array}$ & $\begin{array}{l}\text { ギプスシーネ固定 } \\
\text { リーメンビューゲル }\end{array}$ & 治療 & $\begin{array}{l}\text { 左先天性股 } \\
\text { 関節脱帠 }\end{array}$ \\
\hline 2 & 男 & " & " & " & $\begin{array}{l}\text { 第 } 1 \text { 子頭位分婏 } \\
\text { 出生洔体重3750 g }\end{array}$ & メタルシーネ固定 & " & 右足趾変形 \\
\hline 3 & 女 & $"$ & " & " & $\begin{array}{l}\text { 第 } 1 \text { 子早期破水 } \\
\text { 頭位分婏 出生洔 } \\
\text { 体重 } 3385 \mathrm{~g}\end{array}$ & " & " & 右 鉤 \\
\hline 4 & 女 & " & 右 & 度 & $\begin{array}{l}\text { 第 } 1 \text { 子妊娠中毒症 } \\
\text { 頭位分婏 出生侍 } \\
\text { 体重 } 290 \mathrm{~g}\end{array}$ & " & " & " \\
\hline
\end{tabular}


表 2 合併症（松森）

\begin{tabular}{|c|c|}
\hline 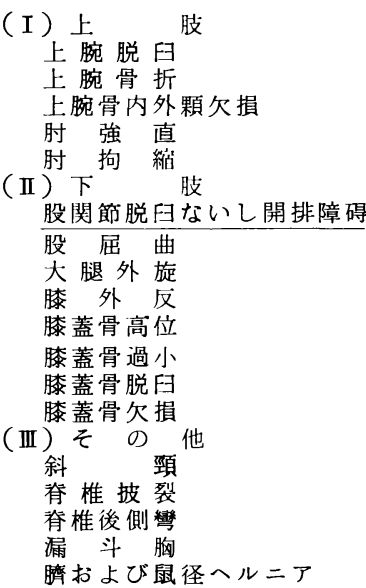 & 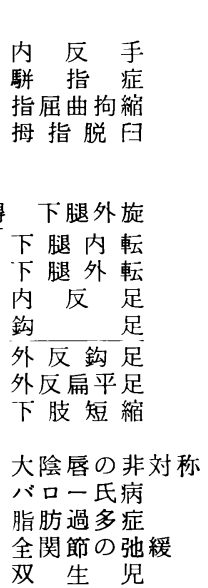 \\
\hline
\end{tabular}

表 3 病因分類 (Provenzano)

1）内因性（子宮内因子）

a ) 1 次性の中胚葉性欠損によるもの

b ) 外傷性の発育障害によるもの

(1) 妊娠早期の子宮内異常肢位に上るもの

(2) 中肧葉性欠損の既存するすのに2 次的

に子宮内異常肢位の加わったもの

c）先天性の大腿四頭筋短縮によるもの

2）外因性

(Middleton)

分婏時の異常肢位によるもの

宮内因子）之外因性（分婏時の異常肢位）とに分けて いる (表 3 ). われわれは手術例むなく，症例数む少 ないため, 何ら根拠をあちあわせていないが, 股関節 脱臼の合併が多いことより, 骨盤位で䐂伸展位に保た れることが関与しているのではないかと考える.治療 としては，牽引整復固定の保存的治療を原則とし，早 期にこれを行なえば，本疾患のほとんどが完全に治瘉
すると言われている．保存的治療で難治性のものは手 術適応が考えられる.われわれの症例はいずれも24 週の保存的治療にて軽快した，出生直後に異常を発 見し，早期に治療を加えたため全例良結果が得られた あのと思われる.

$$
\text { ま と め }
$$

先天性膝関節脱臼 4 例（男㫛 1 例，女児 3 例） 4 関 節を報告した．先天性股関節脱臼 1 例，鈎足 2 例，足 趾の変形 1 例を合併し，いずれも生後ますなく保存的 治療にて軽快した。

\section{文献}

1) 三木：日整会誌，11,96. 昭 11 .

2) 永山：整形外科, 21 巻, 6 号, 475 . 昭 45 .

3）松森：臨床雑誌外科, 18巻 3 号, 205. 昭31.

4) Drehmann, Gustav: Die congenitalen Luxationen des Kniegelenks. Z. Orthop. 7 : 459-521, 1900.

5) Laurence, M.: Genu recurvatum congenitum, J. Bone Joint Surg. 49B: 121, 1967.

6) Neibauer, J. J., and King, D. E.: Congenital dislocation of the knee, J. Bone Joint Surg. 42A : 207, 1960.

7) Provenzano, R. W.: Congenital dislocation of the knee, N. Engl. J. Med. 236: $360,1947$.

\section{発 言宮崎医大 木村 千似}

Jachjian の成書には，本症初期の保存的治療とし ては Castを 8 週, Schale を 4〜6力月書いてあ るが, 1 ～週で治ゆするという演者らの経験は, 参 考にさせて頂き度い. 